\title{
Funding and Delivery Models for Modern Energy Cooking Services in Displacement Settings: A Review
}

\author{
Iwona Bisaga $* \mathbb{\infty}$ and Long Seng To \\ Centre for Sustainable Transitions: Energy, Environment and Resilience (STEER), Geography and Environment, \\ School of Social Sciences and Humanities, Loughborough University, Loughborough LE11 3TU, UK; \\ 1.to@lboro.ac.uk \\ * Correspondence: i.m.bisaga@lboro.ac.uk
}

check for updates

Citation: Bisaga, I.; To, L.S. Funding and Delivery Models for Modern Energy Cooking Services in Displacement Settings: A Review. Energies 2021, 14, 4176. https:// doi.org/10.3390/en14144176

Academic Editor: Fabrizio Ascione

Received: 25 May 2021

Accepted: 6 July 2021

Published: 10 July 2021

Publisher's Note: MDPI stays neutral with regard to jurisdictional claims in published maps and institutional affiliations.

Copyright: (C) 2021 by the authors. Licensee MDPI, Basel, Switzerland. This article is an open access article distributed under the terms and conditions of the Creative Commons Attribution (CC BY) license (https:// creativecommons.org/licenses/by/ $4.0 /)$.

\begin{abstract}
Cooking with modern energy fuels and technologies has a high potential to positively impact the users' health and well-being, and make cooking safer and less burdensome for women and girls. To date, there have been numerous interventions targeting improved cooking solutions in displacement settings, but very few which have involved modern energy cooking, such as ethanol, biogas, LPG or electric cooking. They have been largely absent from humanitarian programming due to limited availability, affordability and lack of business models that suit those complex settings. Additionally, energy access services in displacement settings have historically relied primarily on grant-based funding. However, grants are limited to relatively short timeframes which do not align with the long-term needs of the displaced. New ways of funding energy access in displacement settings, and particularly modern energy cooking services, are urgently needed to address the scale of the challenge as the number of displaced surpassed 80 million in 2020 , with close to $90 \%$ having little or no access to adequate cooking fuels and technologies. In this paper, we review modern energy cooking in displacement settings and the common ways of funding and delivering them. We argue that new ways of funding and delivering energy access in displacement settings are urgently needed to address the scale of the challenge and to facilitate transitions to modern energy cooking fuels and technologies, in line with Sustainable Development Goal 7 and the principle of 'leaving no one behind'.
\end{abstract}

Keywords: SDG7; modern energy cooking; clean cooking; energy finance; displacement; humanitarian energy

\section{Introduction}

Progress on achieving universal access to clean, modern, safe and affordable energy for cooking globally has been slow. Historical investment flows into the sector have been insufficient to meet Sustainable Development Goal 7 (SDG 7; universal energy to clean cooking for all) by 2030 [1]. Despite the increase in private sector investment and the highest amount of capital reaching USD70 million raised by clean cooking companies in 2019 [1], 4 billion people still do not have access to clean, modern, safe and affordable energy cooking services [2]. According to the International Energy Agency (IEA), between 2.5 to 4 million people globally die prematurely due to indoor air pollution [3]. Much of it comes from cooking fuels, such as kerosene, firewood, charcoal or other biomass burned on traditional, inefficient cookstoves. That number also includes many of the over 80 million forcibly displaced people with approx. 26 million refugees, 46 million internally displaced people (IDPs), 4.2 million stateless people, and 4 million asylum seekers [4] who reside in camp, rural, peri-urban or urban settings alongside host communities. Displaced populations include refugees who have crossed an international border to seek safety, and IDPs who have moved within their country to avoid conflict [5]. Fleeing homes to seek safety from conflict, persecution or disasters, they face severe challenges in accessing energy. Evidence suggests that over $90 \%$ of the displaced in refugee camps have minimal 
access to lighting, while $80 \%$ have the absolute minimum of energy required for cooking. Like others who currently do not benefit from clean, modern energy for cooking, including communities who host them, they tend to resort to polluting, inefficient and expensive fuels, e.g., charcoal, firewood or kerosene [6]. This jeopardizes the health and safety of the displaced, as well as the environment in which they and host communities reside [7]. Displaced women and children are exposed to health and safety risks while collecting firewood. They often search for hours and carry heavy loads, which poses risk of genderbased violence, dehydration, and physical injury [8]. Cooking and lighting homes with smoky, polluting fires causes respiratory and eye diseases, affecting health, productivity and educational performance in children. Additionally, lack of access to clean and efficient cooking technologies has detrimental impacts on food security in displacement settings. The resulting environmental degradation due to resource depletion not only contributes to climate change but can also lead to conflict between the displaced and host communities [9]. Energy access, and access to clean, modern cooking solutions in particular, is therefore critical as it advances not only SDG 7 but other SDGs, including good health and well-being, gender equality, climate action, peace and justice, and elimination of poverty [10,11].

Energy access has historically been excluded from humanitarian response and displacement settings, which we define as inclusive of the displaced people and host communities. In recent years, the issue has gained some traction. However, free hand-outs and donations of energy technologies for cooking, lighting and other energy services have dominated this space, resulting in inadequate solutions ill-suited for meeting the needs of the displaced [12]. The short timeframes of donor funding mean that humanitarian agencies' programming may not align with the long-term needs in protracted crisis situations. Refugees and displaced people can be housed in camps or informal settings for generations without access to modern electricity and cooking services. While average durations of displacement across different groups (refugees, IDPs, asylum seekers) fluctuates, depending on the number of newly displaced people every year and the location, the mean duration of exile as experienced by refugees stands at between 10-15 years [13].

Attempts to raise the global profile of humanitarian energy access have recently been gaining traction, with the establishment of the UN-led Global Platform for Action on Sustainable Energy in Displacement Settings (GPA) and UNHCR's Clean Energy Challenge (CEC) [14], which aim to enable all displaced to access energy safely and sustainably in line with the UN 2030 Agenda for Sustainable Development [15]. These initiatives signal a growing recognition of the scale of the challenge and political commitment to tackling it among diverse stakeholders. As a result, new energy delivery models have been explored. A delivery model is "the combination of the technology, finance, management activities, policy support, legal arrangements and relationship types required to supply energy to a group of people or end users" [16] (p. 9), in this case to the displaced people. Traditionally, humanitarian agencies have delivered energy access solutions directly to the displaced through inkind distributions or service provision. Recognizing the shortfalls of such approaches in reaching scale and doing so sustainably, market-based approaches, where the provision of energy services is led by the private sector, have been increasingly promoted [17]. Examples include the involvement of private sector providers under the Moving Energy Initiative (MEI) [18]; the Market-Based Energy Access (MBEA) program led by SNV [19]; and the Energy Solutions for Displacement Settings (ESDS) project led by the German development agency (Deutsche Gesellschaft fur Internationale Zusammenarbeit (GIZ)) [20]. Finding new finance and business models for modern energy cooking services (MECS) in displacement settings is part of a broader discussion on addressing the funding gap in humanitarian assistance through new ways of working [21], including a "shift from funding short-term individual projects and activities to financing outcomes that meet needs and reduce vulnerability" [21] (p. 10).

Yet, despite the recent shifts and advances in moving away from the procure-distribute models commonly resorted to in humanitarian aid, displaced people still struggle with access to clean, modern energy services as donor funding remains scarce and insufficient 
to tackle the challenge at scale, and commercial investors continue to shy away from what is perceived as risky and unprofitable settings, such as refugee camps or informal settlements where many of the urban displaced reside [22]. The goal of this review paper is three-fold: to map out MECS projects (or interventions) in displacement settings to date; to review the delivery models used for such services with the focus on funding and financing mechanisms and business models (where applicable) for different modern energy cooking technologies; and to propose appropriate funding and financing mechanisms and delivery models, drawing on the evidence from the wider energy sector, in order to impact future design of such projects with the view of making them scalable. By doing so we aim to fill in the existing gap in the body of knowledge on MECS in displacement contexts and the common ways of funding them, pointing to the relative absence of financial innovation in the sector and highlighting opportunities for learning from other energy sectors. We argue that in order to truly leave no one behind, new ways of funding, financing and delivering energy access in displacement settings are urgently needed to address the scale of the challenge and to facilitate transitions to modern energy cooking fuels and technologies, in line with SDG7.

Section 2 introduces the methods and definitions used in this review. Section 3 presents a review of MECS projects in displacement settings, with an emphasis on funding and delivery models, and discusses the challenges associated with the implementation of MECS projects in such settings. It also outlines challenges associated with the implementation of MECS in displacement contexts and explores examples of non-grant (or donor) funded MECS interventions. As there are still relatively few examples of MECS projects in displacement settings that make use of innovative delivery and finance approaches, Section 4 offers examples of different financing and business models for MECS from the broader cooking energy sector and draws on the experience of innovative approaches in the wider energy access space, including off-grid electrification. Section 5 offers a critical discussion of the presented evidence and is followed by Section 6 with conclusions and recommendations for humanitarian actors, policymakers and governments hosting displaced populations, as well as the private sector and academia.

\section{Methods and Definitions}

The paper aimed to map out MECS projects in displacement settings to date and review the ways such projects have been commonly funded to establish the status of financial innovation in the implementation of MECS in displacement contexts. We define displacement settings (or contexts, situations-all used interchangeably) as settings where displaced populations reside, including refugee and IDP camps, rural, peri-urban and urban areas, inclusive of the host communities. The review has focused on Africa and South Asia which cumulatively host over 20 million displaced people. The regional focus has been driven by the priority countries of the Modern Energy Cooking Services program, under which this research has been conducted, and based on the countries identified as among the most likely to transition to MECS by 2030 [23]. We refer to MECS as Tier 4 and 5 of the ESMAP's multi-tier framework (where Tier 0 is no access and Tier 5 is the highest level of access) energy for cooking which includes biogas, LPG, ethanol, electricity, natural gas and solar (BLEENS) [24]. We therefore exclude fuels such as firewood, charcoal, dung or kerosene, and improved combustion technologies, such as improved cookstoves (ICS), in the definition of MECS.

The review has considered academic journal publications as well as grey literature (reports, white papers, briefs and websites containing relevant information) that focus on MECS, their funding and/or financing and delivery models in situations of displacement. Given the scope and the goal of this review, publications on non-MECS solutions, such as improved cookstoves, were excluded. Only literature published in or after the year 2000 (and up to 2021) were considered as a way of excluding literature that might be too dated. The review has identified gaps in the existing literature on MECS in displacement settings, which has influenced the review process. As a result, a two-stage literature 
analysis was deployed: an initial literature search was followed by literature snowballing where references in the identified relevant publications were scanned for further evidence. Given the very limited peer-reviewed literature on the subject, the review was expanded to include non-peer-reviewed, grey literature.

Both peer-reviewed publications and grey literature were included for more contextual, general evidence on cooking in displacement settings and to draw lessons on funding, financing and business models from other energy access efforts within energy for cooking and the electricity sector. However, those texts have not been part of the initial literature search and snowballing which focused specifically on MECS project examples, MECS' funding, financing and delivery models in displacement contexts.

Web of Science, ScienceDirect and Google Scholar databases were scanned for literature on the subject. Queries consisted of combinations of keywords including "modern energy cook*", "displace*", "fund* OR financ*", "delivery model", "refugee", and "humanitarian". In one of the rounds of queries, different BLEENS were specified where a combination of the above keywords was followed by modern energy cooking fuels (individually or jointly). The selection of databases allowed for both a thorough search of the academic, peer-reviewed literature, as well as grey literature which is included in the Google Scholar search engine. Different queries returned results ranging from 0 relevant publications (on Web of Science and ScienceDirect but not on Google Scholar) to thousands of publication items. However, very few items returned in the searches matched all the criteria, i.e., focus on MECS, funding or financing or delivery models and displacement settings. The process of evaluating the returned entries, where at least two of the search criteria were highlighted, involved scanning the publication title, keywords, abstract and highlights, where available, depending on the type of publication. Ultimately, the review identified 20 implemented and one planned MECS projects or interventions in displacement settings in the defined geographical area in 23 sources, including peer-reviewed papers, reports, websites and research briefs.

\section{Results}

\subsection{MECS in Displacement Settings}

While precise numbers of displaced people relying on inefficient and polluting cooking fuels and technologies are not known due to the general scarcity of humanitarian energy data [25], in refugee camps that number can be as high as $80 \%$ with an estimated firewood demand of $0.7-3 \mathrm{~kg}$ per person per day [6,26]. Only a small proportion of that demand is satisfied through fuel distribution by humanitarian organizations [27]. In 2014, efforts to support refugees' cooking needs with firewood required USD2.1 billion and the amount of firewood and charcoal burnt by refugees reached 3.9 million tons of oil equivalent, hitting 14.3 million tons of $\mathrm{CO}_{2}$ in emissions [26]. Given the year-on-year growth of the number of displaced people globally, that amount has only increased since. The growing demand for cooking fuels and the associated social, environmental, health and financial impacts on the refugees and the humanitarian organizations have prompted a re-thinking of the way energy for cooking is provided to refugees [28,29]. IDPs and other displaced have been faced with similar challenges, particularly those who fall under the protection of humanitarian agencies and reside in camp or remote locations, removed from local markets and opportunities [30].

Despite the urgency and the scale of the issue, progress on the diffusion of cleaner and more efficient MECS in displacement settings has been slow and has only started gaining momentum in the last five years. The Global Alliance of Clean Cookstove (GACC), now known as the Clean Cooking Alliance (CCA), conducted a review of energy for cooking projects and identified 133 projects in displacement settings between 1983 and 2015 in Africa and South-East Asia [31]. The Gaia Foundation ethanol project in three refugee camps in Jijiga, Ethiopia (2005-2017) was the only project in GACC's review which focused on MECS rather than improved biomass combustion [32]. In addition, we have identified at least five solar cooking projects in refugee camps in Chad, Burkina Faso, 
Nepal, Kenya and Sudan in the last two decades [33-37], and two LPG projects in Sudan (2005-2007, and 2008-ongoing) supported by Practical Action, targeting both refugee, host community and IDP households [38,39]. However, since 2015 the number of MECS projects and interventions in settings of displacement has been steadily growing, with five implemented LPG projects in the Nyarugusu refugee camp (Tanzania), the Cox's Bazaar refugee camps (Bangladesh), the Karin state IDP camps (Myanmar), the Mahama and Mugombwa refugee camps (Rwanda), the Diffa region in Niger, and the Zaatari and Azraq refugee camps (Jordan), and another one pending in the Kakuma refugee camp (Kenya); two electric cooking (e-cooking) projects in the Bidibidi refugee camp (Uganda) and in the Kapen and Kapaungpin IDP settlements (Myanmar); and four biogas projects: one in the Kakuma refugee camp (Kenya), one in Bambasi and Assosa refugee camps in Ethiopia, one in Malakal refugee camp in South Sudan, and one in the Gaza strip and the West Bank. Table 1 presents a summary of the MECS projects identified in our review in a chronological order (including the ethanol project in Jijiga, Ethiopia), offering project details and means of funding. We differentiate between donor and grant funding where donor funding refers to continuous funding support from a bilateral or multi-lateral agency, or a non-governmental organisation (NGO), over the course of the project's duration; and grant funding refers to funding provided by a grant-making institution (e.g., public agency or charitable foundation) to another entity for a specific purpose which is linked to a public benefit (or social impact) and has a defined timeline. Further, we distinguish between funding and financing where the former is money provided by companies or by a government for a particular purpose, whereas the latter is a process of receiving money (or capital) from financial institutions, such as banks or other lenders, for the purpose of business.

In subsequent sections, we analyze the trends and types of implemented projects, and the key barriers to the implementation of MECS in displacement settings.

Table 1. MECS projects in displacement settings (1995-2021). Marked in bold under 'Funding' are MECS projects which had a component of non-grant/donor funding or innovative financing. Adapted from Tran, Bisaga and To [40] (pp. 27-28) and expanded.

\begin{tabular}{|c|c|c|c|c|c|}
\hline Year & Country & $\begin{array}{l}\text { Displacement } \\
\text { Location }\end{array}$ & $\begin{array}{c}\text { Cooking } \\
\text { Fuel/Source/Technology }\end{array}$ & Details & Funding \\
\hline 1995-2013 & Nepal & $\begin{array}{l}\text { Beldangi refugee } \\
\text { camp }\end{array}$ & $\begin{array}{l}\text { Solar parabolic cookers } \\
\text { (combined with heat } \\
\text { retention solutions) }\end{array}$ & $\begin{array}{l}\text { Vajra Foundation Holland project } \\
\text { with financing from the Dutch Lottery } \\
\text { and NGO Stichting Vluchteling; } \\
85,000 \text { solar parabolic cookers, freely } \\
\text { distributed to Bhutanese refugees in } \\
\text { Nepal [35] }\end{array}$ & Grant \\
\hline 2003-2004 & Kenya & $\begin{array}{l}\text { Kakuma and } \\
\text { Dadaab refugee } \\
\text { camps }\end{array}$ & Solar parabolic cookers & $\begin{array}{l}\text { UNHCR projects. } 720 \text { solar parabolic } \\
\text { cookers in Dadaab and } 130 \text { in } \\
\text { Kakuma, freely distributed (and } \\
\text { complementary to the freely } \\
\text { distributed firewood) [36] }\end{array}$ & Donor \\
\hline 2005-2007 & East Sudan & $\begin{array}{l}\text { Kassala state } \\
\text { (IDPs and host } \\
\text { community) }\end{array}$ & LPG & $\begin{array}{c}\text { Kassala Women Development } \\
\text { Association Network (KWDAN), } \\
\text { Practical Action, UK Department for } \\
\text { International Development (DFID) } \\
\text { project; loans supplied by Practical } \\
\text { Action to cover the upfront cost of } \\
\text { LPG + revolving fund established; } \\
1500 \text { households [38] }\end{array}$ & $\begin{array}{l}\text { Grant, followed by } \\
\text { revenue from the } \\
\text { established } \\
\text { revolving fund }\end{array}$ \\
\hline 2005-2017 & Ethiopia & $\begin{array}{l}\text { Four refugee } \\
\text { camps in Jijiga } \\
\text { (Kebribeyah, } \\
\text { Awbere, Sherkole } \\
\text { and Sheder) }\end{array}$ & Ethanol & $\begin{array}{l}\text { Gaia Association (local Ethiopian } \\
\text { NGO), UNHCR. } 8731 \text { stoves freely } \\
\text { distributed to refugee households [32] }\end{array}$ & Grant/donor \\
\hline
\end{tabular}


Table 1. Cont.

\begin{tabular}{|c|c|c|c|c|c|}
\hline Year & Country & $\begin{array}{l}\text { Displacement } \\
\text { Location }\end{array}$ & $\begin{array}{c}\text { Cooking } \\
\text { Fuel/Source/Technology }\end{array}$ & Details & Funding \\
\hline $\begin{array}{l}2005- \\
\text { ongoing }\end{array}$ & Chad & $\begin{array}{l}\text { Six camps } \\
\text { hosting Sudanese } \\
\text { refugees }\end{array}$ & $\begin{array}{l}\text { Solar semi-parabolic } \\
\text { cookers }\end{array}$ & $\begin{array}{l}\text { Fair Climate Fund project (originally } \\
\text { ran by Tchad Solaire and CORD with } \\
\text { grant funding from Jewish World } \\
\text { Watch and Kozon Foundation); } \\
\text { approx. 50,000 solar cookers, freely } \\
\text { distributed. Since 2019, project } \\
\text { supported by Gold Standard } \\
\text { certification of } \mathrm{CO}_{2} \text { savings, resulting } \\
\text { in carbon credits which allow for } \\
\text { continued distribution of the cookers } \\
{[33,39]}\end{array}$ & $\begin{array}{l}\text { Grant, followed by } \\
\text { carbon credits }\end{array}$ \\
\hline $\begin{array}{l}2008- \\
\text { ongoing }\end{array}$ & $\begin{array}{l}\text { North } \\
\text { Darfur, } \\
\text { Sudan }\end{array}$ & $\begin{array}{l}\text { IDPs and local } \\
\text { residents in El } \\
\text { Fashir (urban } \\
\text { capital of North } \\
\text { Darfur) }\end{array}$ & LPG & $\begin{array}{l}\text { Practical Action, Carbon Clear and } \\
\text { WDAN project (follow on to } \\
\text { 2005-2007 Sudan project); carbon } \\
\text { financed loans to cover the upfront } \\
\text { cost of LPG fuel and equipment + } \\
\text { establishment of revolving fund; over } \\
\text { 10,900 stoves by } 2016 \text { [41] }\end{array}$ & $\begin{array}{l}\text { Carbon finance and } \\
\text { revenue from the } \\
\text { established } \\
\text { revolving fund }\end{array}$ \\
\hline 2013-2016 & Burkina Faso & $\begin{array}{l}\text { Goudoubo, } \\
\text { Saag-Nioniogo, } \\
\text { Mentao refugee } \\
\text { camps }\end{array}$ & $\begin{array}{l}\text { Solar parabolic } \\
\text { cooker/cook box }\end{array}$ & $\begin{array}{l}\text { UNHCR under the 3-year SAFE } \\
\text { strategy programme; two types of } \\
\text { solar cookers: the Devos and the } \\
\text { Blazing Tube (BT), freely distributed } \\
\text { (number n/d) }[34,41]\end{array}$ & Donor \\
\hline 2014 & $\begin{array}{l}\text { Gaza and } \\
\text { West Bank }\end{array}$ & $\begin{array}{l}\text { Rural households } \\
\quad \text { in Gaza }\end{array}$ & Biogas & $\begin{array}{l}\text { American Near East Refugee Aid } \\
\text { (ANERA) project; } 15 \text { biodigesters } \\
\text { freely distributed to rural households } \\
\text { in Gaza and } 13 \text { to marginalised } \\
\text { Bedouin families in West Bank [41] }\end{array}$ & Grant/donor \\
\hline 2016-2017 & Tanzania & $\begin{array}{l}\text { Nyarugusu } \\
\text { refugee camp }\end{array}$ & LPG & $\begin{array}{l}\text { UNHCR project. Pilot } n=3000 \mathrm{HHs} \\
\text { received free LPG kits and two refills } \\
\text { of } 6 \mathrm{~kg} \text { LPG per month over a } \\
\text { 3-month period [42] }\end{array}$ & Donor \\
\hline 2016-N/D & Ethiopia & $\begin{array}{l}\text { Bambasi and } \\
\text { Assosa refugee } \\
\text { camps }\end{array}$ & Biogas & $\begin{array}{c}\text { Horn of Africa Regional Environment } \\
\text { Centre and Network (HOAREC) with } \\
\text { commercial partner (B)energy } \\
\text { (German manufacturer of mobile } \\
\text { biogas technology); biogas digesters } \\
\text { or biogas backpacks sold to refugee } \\
\text { and host community households; } \\
\text { adopters benefit from profit from } \\
\text { supplying biogas or effluent } \\
\text { (fertilizer) [41] }\end{array}$ & $\begin{array}{l}\text { Grant and private } \\
\text { finance }\end{array}$ \\
\hline 2017 & Jordan & $\begin{array}{l}\text { Zaatari and } \\
\text { Azraq refugee } \\
\text { camps }\end{array}$ & LPG & $\begin{array}{l}\text { LPG cylinders freely distributed to } \\
\text { Syrian refugees as part of UNHCR's } \\
2017 \text { winterization support [43] }\end{array}$ & Donor \\
\hline $\begin{array}{l}2018- \\
\text { ongoing }\end{array}$ & Bangladesh & $\begin{array}{l}\text { Kutupalong and } \\
\text { the other refugee } \\
\text { settlements Cox's } \\
\text { Bazar district }\end{array}$ & LPG & $\begin{array}{l}\text { UNHCR, IOM, FAO, Government. } \\
\text { Project scaled to entire camp n }= \\
\text { 99,103 HHs ( } 88,385 \text { refugee HHs and } \\
\text { 10,718 host communities HHs); LPG } \\
\text { kits freely distributed [44] }\end{array}$ & Donor \\
\hline $\begin{array}{l}\text { 2018- } \\
\text { ongoing }\end{array}$ & Niger & $\begin{array}{l}\text { Diffa region } \\
\text { (IDPs and } \\
\text { Nigerian } \\
\text { refugees) }\end{array}$ & LPG & $\begin{array}{l}\text { UNHCR led project in partnership } \\
\text { with a private sector provider of LGP; } \\
\text { UNHCR supports the initial cost of } \\
\text { the first } 6 \mathrm{~kg} \text { bottle of gas (approx. } \\
\$ 40) ; 5 \mathrm{LPG} \text { stations and } 30 \text { LPG refill } \\
\text { points established by the private } \\
\text { sector; over } 225,000 \text { displaced people } \\
\text { reached, plus over } 4000 \text { non-displaced } \\
\text { households [ } 45]\end{array}$ & $\begin{array}{l}\text { Donor and private } \\
\text { finance }\end{array}$ \\
\hline 2019 & Uganda & $\begin{array}{l}\text { Bidibidi refugee } \\
\text { camp }\end{array}$ & eCook (ECOCA) & $\begin{array}{c}\text { Pesitho, Caritas Denmark. } 50 \\
\text { cookstoves freely distributed to } \\
\text { households ( } 38 \text { refugee and } 12 \text { host } \\
\text { community) [46] }\end{array}$ & Grant \\
\hline
\end{tabular}


Table 1. Cont.

\begin{tabular}{|c|c|c|c|c|c|}
\hline Year & Country & $\begin{array}{l}\text { Displacement } \\
\text { Location }\end{array}$ & $\begin{array}{c}\text { Cooking } \\
\text { Fuel/Source/Technology }\end{array}$ & Details & Funding \\
\hline 2019 & Myanmar & $\begin{array}{l}\text { IDPs in Kapen } \\
\text { and Kapaungpin }\end{array}$ & eCook (ECOCA) & $\begin{array}{c}\text { Pesitho, Caritas Denmark.ECOCA } \\
\text { cookstoves freely distributed to } 50 \\
\text { IDP households [46] }\end{array}$ & Grant \\
\hline $\begin{array}{l}2019- \\
\text { ongoing }\end{array}$ & Rwanda & $\begin{array}{l}\text { Mahama refugee } \\
\text { camp (and } \\
\text { Mugombwa } \\
\text { refugee camp } \\
\text { since 2021) }\end{array}$ & LPG & $\begin{array}{l}\text { Ministry of Charge of Emergency } \\
\text { Management (MINEMA) and } \\
\text { UNHCR Rwanda; approx. 11,000 LPG } \\
\text { cookstoves provided by SafeGas } \\
\text { (tendered LPG provider), freely } \\
\text { distributed (part supported by Red } \\
\text { Cross) with paid LPG refills from the } \\
\text { same provider }[47,48]\end{array}$ & $\begin{array}{l}\text { Donor, public and } \\
\text { private finance }\end{array}$ \\
\hline 2020 & Myanmar & $\begin{array}{l}\text { Two IDP camps } \\
\text { in Karin State }\end{array}$ & LPG & $\begin{array}{l}\text { Spectrum (NGO); tendered provider } \\
\text { of LPG; } 50 \text { IDP households }[49,50]\end{array}$ & Grant/donor \\
\hline 2020-2021 & Kenya & $\begin{array}{l}\text { Kakuma refugee } \\
\text { camp and } \\
\text { Kalobeyei } \\
\text { settlement }\end{array}$ & Biogas & $\begin{array}{c}\text { Action Africa Help International } \\
\text { (AAHI), Water Fund and Danida; } 100 \\
\text { biogas digestors freely distributed to } \\
\text { farmers (refugee and host community) } \\
\text { [51] }\end{array}$ & Grant \\
\hline $\begin{array}{l}2020- \\
\text { ongoing }\end{array}$ & South Sudan & $\begin{array}{l}\text { Malakal refugee } \\
\text { camp }\end{array}$ & Biogas & $\begin{array}{l}\text { Project led by the International } \\
\text { Organization for Migration (IOM) }\end{array}$ & $\mathrm{N} / \mathrm{D}$ \\
\hline 2021 & East Sudan & $\begin{array}{l}\text { Um Rakuba and } \\
\text { Tunaydbah } \\
\text { refugee camps }\end{array}$ & Solar box cookers & $\begin{array}{l}\text { UNDP; } 900 \text { solar box cookers, freely } \\
\text { distributed to refugees in the two } \\
\text { camps and to nearby host } \\
\text { communities [37] }\end{array}$ & Donor \\
\hline Proposed & Kenya & $\begin{array}{l}\text { Kakuma refugee } \\
\text { camp }\end{array}$ & $L P G$ & $\begin{array}{l}\text { MEI, KNOX, proposed pilot for } 5400 \\
\text { refugee households over } 24 \text { months using } \\
\text { a concession with a Results-Based } \\
\text { Financing (RBF) component [42] }\end{array}$ & $\begin{array}{c}\text { Grant (concession } \\
\text { with RBF) }\end{array}$ \\
\hline
\end{tabular}

\subsection{Challenges of MECS Implementation}

The 20 implemented and one proposed MECS projects across refugee camps and IDP hosting areas included in Table 1, compared to the 132 biomass projects up until 2015 and many more since, show that MECS in displacement settings are in a nascent stage. They are also a testament to the unique challenges which face the deployment and adoption of MECS in displacement settings. According to Vianello [52], humanitarian contexts are characterized by factors which make modern energy provision more challenging than in non-humanitarian situations. Among them, restrictions on movement of the refugees (mainly in camp locations), employment restrictions and opportunities, resulting in limited resources and ability to pay for energy services, governance issues concerning the split between the displaced people and the host communities, and the sense of dependency on humanitarian aid which can inhibit self-reliance. What is more, particularly contexts such as refugee camps, which are managed by humanitarian organizations and therefore are subject to a unique set of rules and regulations, make for complex environments which are difficult to navigate by non-humanitarian actors [53]. The continued (mis) conception about the displaced as a "discrete and helpless population" [52] (p. 3), and the lack of integration of displaced populations in the national socio-political strategies also perpetuates the dependence on humanitarian aid, as the policy environments remain unfavorable for private sector investment and private sector-led delivery models. Lack of prioritization of modern energy cooking solutions in the humanitarian response has additionally contributed to the limited interest of bringing commercial cooking enterprises into refugee and IDP camps [40]. Finally, lack of consistent funding has been among the most critical barriers to the implementation of MECS projects in humanitarian contexts and to ensuring their long-term sustainability and success [41]. This is expected to become more exacerbated as funding for international humanitarian assistance is at risk of getting 
cut due to development aid reductions in high-income countries, the economic impacts of COVID-19 and resulting downward trends in remittances, investments and trade [54].

The combination of these factors has shaped the landscape of energy access in settings of displacement. Consequently, a range of donor-funded improved cooking solutions being deployed, typically under a procure-distribute delivery model or provided by NGOs or private companies with grant funding from a range of charities, foundations and other organizations with an interest in energy access in displacement settings. Such freely distributed or donated solutions have offered a way of tackling the pressing cooking challenge, especially in camp locations which are often removed from local markets due to their remoteness and/or isolation. However, under such models, the challenge can hardly be addressed at scale as the number of products, or the duration of services, is dictated by the amount of grant funding available and the relatively short timelines under which such funding is usually disbursed [55]. Similarly, other than selected few projects, MECS solutions have been predominantly funded by donors and grant funding, with a procuredistribute delivery model being the most common. Out of the 21 MECS interventions presented in Table 1, all but one relied on donor and/or grant funding, with further two projects incorporating additional funding components (such as a revolving fund acting as micro-finance and carbon credits) and another three having incorporated commercial funding from the private sector. Recently, such alternative delivery models adopting market-based approaches, involving private sector providers or community-based organizations (CBOs), as well as more innovative blended financing, such as grants in conjunction with carbon credits or results-based financing (RBF), have started emerging.

\subsection{Beyond Grants' MECS Interventions in Displacement Settings}

The CEC envisions the delivery of universal, low-carbon energy access to all displaced by 2030 [14]. Given that traditional approaches to financing energy access have been sparse due to the high risk, low return of this market opportunity, the CEC also advocates for non-grant-based funding of energy access options with a greater engagement of the private sector in the design of delivery models in order to develop sustainable market-based approaches and local market capacities [14,56]. While grant funding can be helpful in supporting private sector providers to start up operations in settings such as refugee camps, which might be removed from their existing operations and more challenging to enter due to the range of logistical and administrative challenges [28], there is a need to build in financial sustainability into the delivery models so that the reliance on grants is removed over the long term. Blended finance, which strategically utilizes development finance to attract additional finance, including commercial capital, to support projects in pursuit of SDGs that private investors would otherwise not consider [57], has been gaining traction in the wider energy access sector, including MECS. Yet to date, only a few alternative financing and blended finance mechanisms have been deployed in MECS interventions in settings of displacement. The more innovative ones have included carbon financing, carbon financing combined with micro-finance (in a form of revolving funds), and concessions (though not yet successfully executed), while others have brought in commercial funding from private sector energy providers.

Carbon financing is an innovative funding tool that falls under environmental finance and puts a financial value on carbon emissions thus enabling companies who want to offset their emissions to purchase carbon credits earned from sustainable energy projects [58]. Facilitated through the Clean Development Mechanism (CDM) under the Kyoto Protocol to the United Nations Convention on Climate Change (UNFCCC) [59], carbon finance mechanisms are project-based and aim to support project activities which cut carbon emissions, in which clean, modern and renewable energy is an important component [60]. Approved CDM projects produce Certified Emission Reductions (CERs) which can then be traded with other organizations, industries or countries not meeting carbon emission standards [60]. Carbon financing can therefore increase the financial viability of projects by creating an additional revenue stream [61]. This, in turn, allows for the financing of 
innovative clean energy projects that bring sustainable energy solutions to all segments of the population. In the case of carbon financing of solar cookers in Chad (the Fair Climate Fund project), the carbon credits obtained through the certification of the solar cooking project by Gold Standard-a carbon certification agency established by the WWF and other international NGOs in 2003 [62], have been used to finance solar cooker kits (the CooKit solar cookers) to then distribute them to the refugees at no cost, meaning that the entire capital cost of each kit is covered by revenue from the earned carbon credits. This has allowed Fair Climate Fund to distribute thousands of cooking kits to families across six refugee camps. It is worth noting, however, that the project was initially supported by grant funding and switched to carbon financing in 2019 upon reaching a level of scale which allowed it to demonstrate sufficient carbon emission reductions to be eligible for CERs.

The Practical Action project in North Darfur (Sudan) (a follow-on project capitalizing on the learnings from the 2005-2007 project in East Sudan) has utilized carbon financing in a somewhat different manner. Carbon credits obtained through Carbon Clear-a provider of carbon management and a founding member of the International Carbon Reduction and Offset Alliance (ICROA), have been used as start-up financing to establish a revolving fund managed by WDAN, effectively turning it into a micro-finance provider. The fund allows participating local women to take up a loan to cover the up-front cost of the LPG equipment and fuel, which can otherwise be prohibitively expensive for low-income households [63]. The loan can then be paid off in instalments over time on flexible payment plans. Ongoing repayments are invested back into the fund which then allows other women to take up a loan for their LPG kit [41]. The approach is equivalent to asset financing where customers receive the product up front but pay off its value over time [64], in this case through an intermediary (the WDAN) rather than the energy access solution provider (which is common in off-grid solar electrification projects [65]). This application of carbon financing has addressed the affordability issue by offering flexible loans to remove barriers to adoption of LPG, rather than by providing free distribution of the equipment and fuel, thus enabling the development of a local LPG market. In the context of North Darfur, ongoing monthly LPG refills were very cost competitive, allowing households to save up to $40 \%$ of what they would otherwise spend on charcoal, making the offering attractive for both financial, as well as health (smoke reduction) and convenience (speed of cooking, reduced drudgery) reasons [41]. The ability of both local residents and IDPs residing in the area to earn income has been an enabling factor which contributed to the success of the project. In settings where the displaced people cannot perform paid work, as is the case for refugees in some refugee hosting countries, models like this one might face challenges associated with the ability to pay where households move from unpaid (self-collected) fuels and freely distributed cookstoves to a paid solution. This makes the case for switching much less appealing.

A different mechanism which has to date been explored and designed for implementation, but not yet deployed in displacement settings, is that of a clean cooking concession. The concept was first conceived of as part of the Moving Energy Initiative (MEI) and designed for the introduction of LPG in the Kakuma refugee camp in Kenya. A clean cooking concession in Kakuma would take advantage of the scale of the available market (close to 200,000 refugees and asylum seekers [66], plus the host community of approx. 60,000 residents). Through the concession, the price of the cooking technology and fuel would be subsidized in order to match the existing cooking expenditure of the households, thus removing the affordability barrier. The concession would cap the fuel price so that refills would also be affordable. Selected through a competitive tender, the private sector provider would inform the design of a results-based framework to set the necessary level of subsidy, thus making it viable for both the provider and the customer. The RBF component would allow for disbursements to the private sector provider upon meeting the established milestones in the number of sales (i.e., households reached). The minimum 3-year timeline of the concession would support the development of a sustainable LPG market after which the provider would be able to maintain the offered prices without a subsidy as at that point 
they would benefit from economies of scale [42,67]). The main goal of a clean cooking concession is to encourage the private sector to establish presence in a market which, without the offered subsidy and support, they would not consider otherwise. Despite the potential it presents, the Kakuma concession is yet to be implemented due to a number of challenges, including requests for further de-risking mechanisms (guarantees, de-risking or returnable grants and/or working capital facilities), which the private sector considered necessary given the novelty of the proposed delivery model and the inherent risks of the setting they would be entering [67].

Finally, private finance has played a role in at least three MECS projects in displacement settings identified in this review. In Ethiopia, a private provider of biogas solutions has established operations in two refugee camps with an initial grant funding provided by the Horn of Africa Regional Environment Centre and Network (HOAREC). The project targeted both the host community members and the refugees. Following the grant-supported entry, energy (the private provider) has operated on a purely commercial basis, deploying sales agents who simultaneously act as technicians to help raise awareness of the biodigesters and biogas backpacks and offer maintenance services and training to build local capacity [41]. Individuals, whether refugees or host community members, can purchase a full biodigester which comes with several biogas backpacks. The advantage offered by the biogas solutions is that adopters can benefit from the sales of either the produced biogas (using the biogas backpacks) or the effluent-a by-product of anaerobic digestion and a rich fertilizer which can be used for agriculture, or both. The ability to profit from the clean cooking solution helps justify the initial cost and has encouraged buy-in from farmers and cattle-owners. The accompanying biogas backpacks have enabled transition to cleaner cooking among the wider community, including refugees and host community members [41].

In Niger, a private sector provider of LPG has invested into establishing operations in the Diffa region-home to over 100,000 refugees and a large IDP population. Under the partnership with UNHCR, who have committed to subsidizing the up-front costs of LPG equipment and the first $6 \mathrm{~kg}$ of gas for the refugees and IDPs, the provider was guaranteed a sizeable market. It has also been able to benefit from reaching non-beneficiary (nonUNCHR supported) households, further boosting their sales and revenue [45]. Similar to the concession model, the provider would likely not enter this market if there was no donor support available to achieve the required level of affordability for the displaced households. However, once scale is reached, affordable refill prices can be maintained as the company benefits from economies of scale.

Finally, in the case of Rwanda, finance from the private sector has aided UNHCR and MINEMA in the implementation of an LPG project to address the cooking needs of refugees in the biggest refugee camp-Mahama, followed by Mugombwa (as of April 2021) which hosts approx. 11,000 refugees. The decision to pursue LPG was made as a result of the October 2018 directive issued by the Government of Rwanda prohibiting the distribution of firewood in the refugee camps in order to stop deforestation. SafeGas, a private provider of LPG, was tendered to provide the technology and the fuel in the Mahama camp, leading to the establishment of the company's operations with one sale and refill point $[47,48]$.

Attracting private financing is among top priorities for policy makers looking to close the infrastructure gap, particularly in low-/low-medium income countries (LMIC). However, to date private finance represents only a minor share of overall infrastructure financing, including for energy access, with LMIC countries struggling to attract private investors [68]. The added complexity of displacement settings makes it even harder to attract it. Blended financing can ease that process by helping facilitate entry of private energy providers through grants or donor funding. The established operations and demonstrable viability can be used to leverage other financing, improving chances of reaching scale and achieving long-term sustainability. 


\section{Innovations in the Wider Energy Sector: Opportunities for MECS in Displacement Settings}

Despite progress being made towards transitioning displaced populations to cleaner cooking and gradually moving away from a sole dependence on donor funding to facilitate it, there are still relatively few examples of MECS projects in displacement settings, and even fewer innovative approaches to delivering and financing them. Understanding the status quo can help identify lessons learned to inform future design of MECS interventions in displacement settings. However, in order to rapidly scale up the available resources to support the implementation of MECS at scale across a range of settings, including refugee and IDP camps, urban and peri-urban areas hosting displaced populations, new delivery models with a more diverse range of financing mechanisms will be needed. Given the nature of MECS solutions, which typically require some level of upfront investment to cover the cost of hardware (e.g., gas cylinders and accompanying equipment in the case of LPG; a biodigester unit in the case of biogas; or electric cooking appliances in the case of electricity), which can be prohibitively expensive to many displaced households, it is worth referring to the wider clean cooking and electrification sectors which have seen more innovative approaches to the delivery and financing of energy solutions being developed and applied in a variety of contexts, including rural and low-income settings.

\subsection{Innovative Business Models}

Where private sector participation is involved, there are at least three business model approaches which could be applicable to displacement settings and which could help speed up the availability and uptake of MECS solutions by alleviating the affordability issue. The first is the Pay as You Go (PAYG) model which has been widely deployed in the off-grid solar electrification sector [69], including in settings of displacement [70], and more recently in the cooking sector with the introduction of PAYG LPG [71]. The PAYG model has been adopted in the energy sector from the mobile telecommunication sector and allows customers flexibility of payments and the ability to break up larger amounts into smaller payments, thus removing barriers to entry. It has been adapted to facilitate two distinct ways of delivering energy access where the customers either purchase a certain amount of credit to use energy and have to top it up once it runs out, or they pay small instalments over a defined period of time (on a daily, weekly or monthly basis) and eventually own the energy technology. The latter is known as a lease-to-own model and has been common in the deployment of off-grid solar home systems (SHS) in rural electrification across Sub-Saharan Africa and parts of Asia, whereas the former has been favored in the provision of electricity through mini-grids [72]. PAYG has the highest potential in settings with an already established telecommunications infrastructure and, in particular, the availability of mobile money (MoMo) solutions on which PAYG providers rely for payments. Alternative modes of payment can include scratch cards or cash payments to providers' agents; however, MoMo transactions have been preferred as they eliminate the risk of fraud, eliminate the burden of cash management and reduce credit risk due to real time payment monitoring [73].

PAYG models rely on asset financing for the energy technologies from the providers or other intermediary financiers. This means that to provide energy technologies under this model is capital intensive as energy technologies, whether SHS, LPG stoves and accompanying equipment or electric pressure cookers (EPC), are covered by the provider up front with the cost recovered, and profit made, over time. Typically, PAYG providers are vertically integrated meaning that they have to navigate the complexity of two distinct value chains as they are effectively providers of energy products and financial loans. This requires a high level of upfront capital from the providers or partnerships with microfinance institutions or other commercial lenders to cover the cost of the offered energy product and do so at scale (i.e., large numbers of products to achieve a favorable price per unit). In order to facilitate that, increasingly off-grid energy providers, as well as providers of LPG, have been accessing debt and equity financing, as well as more innovative financing 
mechanisms. Those most relevant to the provision of MECS in displacement settings are discussed below. Their relevance stems from the urgent need to build markets of MECS by alleviating entry for the providers and to remove barriers to affordability for the end users.

\subsection{Innovative Financing Mechanisms}

Innovative financing schemes and mechanisms can help speed up efforts towards providing all displaced people with access to clean, modern, safe and affordable energy by de-risking investment for the private and public sector providers willing to enter displacement settings, therefore building up the market of energy products and services, and by lowering the price of such products and services for the target populations, thus addressing the affordability issue. They can help create incentives for public and private providers of energy services to access settings such as refugee camps or remote locations hosting displaced communities, which can be more challenging than other contexts, as well as help lower the price of the products and/or services for the target populations. They can also help address the capital expenditure challenge for providers operating under PAYG or similar capital-intensive models. Two innovations in financing energy access projects could be considered for the provision of MECS in displacement settings.

The first one is an RBF mechanism, a component of which has been embedded in the proposed Kakuma energy concession project (see Section 2). Under an RBF, private sector providers of energy technologies are incentivized by payments made after the installation or a delivery of their products or services is completed, typically after a specified number of customers has been reached [74], meaning that payments are received ex-post. Clean cooking (especially ICS) and off-grid electrification RBFs have been implemented in several countries across Sub-Saharan Africa and Asia (e.g., Rwanda, Uganda, Kenya, Tanzania, Cambodia, China and Indonesia) [75-77] as a way to rapidly scale up energy access. However, RBF financing can be seen as a form of subsidy. If energy providers develop a heavy reliance on it, challenges similar to those faced by providers relying on donor or grant funding can arise. The money received under RBF schemes can be used either to support the manufacturing of energy technologies or to other activities, such as marketing and awareness raising, or both. However, making sure that the funds are channeled to activities most effective in supporting access expansion among last mile customer segments can be challenging [78]. Social and development impact bonds are also a form of an RBF where private (impact) investors provide upfront capital for public projects with the goal of delivering social and/or environmental outcomes. If projects prove successful, the investors get repaid with interest by the government, in the case of social impact bonds, or by aid agencies or other philanthropic funders, in the case of development impact bonds. In failed projects, part of the capital is lost, including the interest. This approach is also known as payment-for-result, pay-for-success or as a social benefit bond [79]. These kinds of bonds have been increasingly linked to national-level outcome-based financial facilities in order to reach scale and maximize impact in line with national plans and ambitions, but they should not be compared to other types of bonds, such as green or commercial bonds, which are more sophisticated financial instruments [80].

The second mechanism, so far not explored in MECS projects targeting displacement settings, is peer-to-peer lending (P2P). In P2P, energy providers receive a loan from a group of lenders through a crowdfunding platform. The lenders can be individual or institutional, or both. Crowdfunding platforms are in charge of managing the loans offered to the borrower (i.e., the company or project/program). With the ability to conduct thorough credit checks on the borrowers, they take that responsibility off the hands of individual investors [81], who would otherwise be unlikely to support the participating companies or projects. RBF and P2P mechanisms have also been combined into resultsbased crowdfunding, transforming the financing tools even further [65]. Advances in online crowdsourcing and crowdfunding, and the digitalization of financial instruments have all contributed to the rise of these alternative funding sources $[69,81]$. 


\section{Discussion}

MECS projects and programs supported solely by grant funding face the challenge of long-term financial sustainability as operations are at risk of termination should donor or grant funding be exhausted. This creates uncertainty for the humanitarian organizations running those programs, the providers of energy solutions, and, most importantly, people in displacement settings themselves. Additionally, if the delivery is under the 'procure and freely distribute' model, then there are further challenges associated with (i) the lacking sense of ownership and value attached to the offered solutions in beneficiaries [82,83]; (ii) insufficient training resulting in a misuse, damage or selling of the provided products, thus jeopardizing or negating the intended benefits and impacts [22]; (iii) potential frictions with neighboring host communities who might feel left out and resentful, as they frequently face similar energy access challenges as the displaced; and (iv) the perpetuation of the displaced people's reliance on aid, locking them in a vicious cycle of free products and services which often do not meet their needs [84].

However, while interventions resorting to more innovative financing mechanisms aim to remove the financial sustainability issue (at least in principle and under a number of assumptions, e.g., reaching scale and successfully building local market capacity), they too have to address a range of challenges associated with the delivery model. For example, in the case of carbon financed MECS projects where cooking fuels and technologies are provided at no cost, the same challenge of little or no sense of ownership arises, potentially leading to the solutions being misused, unused, or sold. Where carbon financing or other innovative mechanisms, such as concessions and RBFs, are used to alleviate barriers to entry to MECS for the end-users, issues around the competition with programs distributing free firewood, charcoal or kerosene to refugees or IDPs in the same location can prove prohibitive to their success. Such parallel activities might send confusing messages to the households [41]. As argued by Kasirye et al. [85], lack of proper planning and coordination along with the lack of funding, energy specialists and policy frameworks in and for displacement settings are among the greatest challenges facing energy transitions in such settings. Even though interventions involving some level of subsidization of the cost of MECS, whether through a concession, carbon or micro-financing, or donor funding, can be successful in bringing the cost down sufficiently to reach a large number of displaced households, the on-going costs associated with refills (in the case of LPG) or maintenance (e.g., in the case of biogas) might discourage households from adopting the proposed solutions, particularly if the wider benefits (health, environmental, well-being, time saving, as well as economic/financial) are poorly understood. This can again result in the target groups continuing to cook on biomass, either freely collected (if available in the location) or purchased from local distributors. Where there is a strong component of private sector participation, such as in the case of LPG programs in Niger, Sudan or Rwanda, or the biogas program in Ethiopia, demonstrating the positive impacts the programs have through their investments into local capacity building as well as job creation along the value chains can additionally help convince the target populations to switch to the offered MECS solutions. In the case of LPG, it is important to involve the suppliers from the start, as argued by Bates [86]. To demonstrate market size and viability it is important to show that low-income households can afford to buy LPG. As highest profit margins lie in fuel refills, providers of LPG should offer gas bottles at low prices or with financing, to enable small, incremental payments over time. While some evidence suggests that giving LPG bottles away for free leads to their reselling at local markets, awareness-raising efforts on the benefits of MECS can help avoid that [86].

While the prevalence of the more traditional fuels and cookstoves can pose a significant barrier to the adoption of MECS in displacement settings, there are risks associated with fully and abruptly phasing them out or prohibiting them outright. For example, there have been documented instances of refugees in the Mahama camp in Rwanda being left with no cooking fuel while waiting for LPG distribution [87]. Lack of livelihoods for those along the value chain is another concern. In Niger, UNHCR worked with local 
officials to identify firewood sellers to provide them with cash or other in-kind resources to encourage them to become LPG sellers or delivery providers [42]. Ensuring that the associated distortion of local firewood, charcoal or kerosene markets do not cause damage to either the displaced or host community members, and do not cause conflict among various interest groups, is critical and calls for a close collaboration with all stakeholders, including local leadership, other agencies, organizations or companies operating in the location, as well as the displaced people themselves. Finally, ill-suited MECS solutions can also drive projects' failure. In Burkina Faso, women had to resort to firewood collection due to the inadequacy of the provided solar cooking solutions. Being unable to cook the same amount of food with just the solar cooker, fuel stacking was identified as widespread [34]. This points to the need for any provider of a clean, modern energy cooking solution to get a good understanding of the demand side of the supply chain before rollout so that such unintended consequences can be avoided, and the offered solutions be better suited to the needs and practices of the target customers or groups. This approach aligns with the energy delivery model and recognizes the need for a consideration of the entire value chain [88].

Lastly, the existing examples of MECS in displacement settings point to the need for a closer collaboration between all concerned stakeholders, including host governments, private sector players and financial and development agencies to close the funding gap [89]. This should aim to leverage the resources available to the wider energy access sector to address the challenge in a holistic way which could help speed up transitions to MECS for displaced and host communities at scale and in a sustainable manner.

\section{Conclusions and Recommendations}

In this paper, we have reviewed how MECS projects and programs in Africa and South Asia are funded and how they enable access to clean, modern energy for cooking for people in displacement settings. We have identified 21 interventions focusing on MECS in displacement settings between 1995-2020, out of which 20 have been implemented to date. All but one relied on donor and/or grant funding, with further two projects incorporating additional funding and financing components. Only four of the implemented projects did not involve free distribution. This demonstrates the scarcity of MECS projects in displacement settings, their heavy reliance on grant and donor funding, and free distribution models. We argue that in order to scale up MECS in displacement settings and attract private sector investment and participation, more innovative financing is urgently needed. Although innovations in the way clean cooking solutions, including MECS, are financed can help boost the availability of funding for the cooking sector in displacement settings, the above lessons demonstrate that financing and funding must be considered as part of the wider project or program design. Funding and financing are critical to ensure longevity of cooking interventions and thus their long-term impact, but do not guarantee success on their own. Therefore, a more holistic approach, i.e., a delivery model, is needed with consideration given to entire value chains of energy products and services, as well as the socio-behavioral aspects of energy adoption, the enabling policy environment, institutional frameworks and ongoing projects or programs (to avoid duplication/replication or conflicting messages), and the broader local and national context $[84,85,90]$.

For the innovative business and financing models to be successful and help achieve the scale of MECS in displacement settings needed to significantly reduce the current energy access gap, those models will have to recognize end-users' needs and local dynamics. These include market dynamics and intra-household power dynamics which impact the decision-making regarding energy choice and use. To that end, more context specific data will be required [25]. Lack of data on energy in displacement settings has continued to be a barrier to the involvement of the private sector. Data can not only inform project and program design, but it can also be leveraged to attract investment by demonstrating the viability of displacement settings [91], particularly for novel solutions such as MECS where evidence from interventions undertaken to date is relatively limited. Similarly, evidence 
from the wider energy access sector has the potential to inform humanitarian response in regards to energy access and help bridge the humanitarian-development divide to ensure that interventions tackling humanitarian crises align with, and positively impact, the achievement of long-term sustainable development [92]. There is a yet untapped potential for development finance and impact investing in the form of equity or debt contributions to target displacement settings to further bridge the divide between the development and humanitarian energy sectors. This is particularly pertinent given the opportunities offered by designing inclusive delivery models, targeting both the displaced and host populations. Lessons learned from the implementation of MECS in non-displacement settings will be crucial as similar challenges and opportunities apply to rural, peri-urban and urban displacement settings as do to host communities in those contexts. This is especially important as research on access to MECS among displaced populations in urban areas has been scarce [54,93]. Future research should also include relevant stakeholders such as local and national governments, to ensure the proposed delivery models align with national policies and priorities, as well as investors, financiers and private sector providers active in the energy for development field to better identify the key barriers and opportunities for the design, delivery and financing of MECS in displacement settings.

Author Contributions: Conceptualization, I.B.; investigation, I.B.; writing-original draft preparation, I.B.; writing - review and editing, I.B. and L.S.T. All authors have read and agreed to the published version of the manuscript.

Funding: This research was funded by UK Aid, grant number GB-GOV-1-300123.

Data Availability Statement: Not applicable.

Acknowledgments: The authors would like to thank embers of the Modern Energy Cooking Services program for their feedback collected over the course of consultations to support the humanitarian energy stream which has helped conceptualize and write this paper.

Conflicts of Interest: The authors declare no conflict of interest.

\section{References}

1. Clean Cooking Alliance (CCA). 2021 Clean Cooking Industry Snapshot. Available online: https://www.cleancookingalliance. org/resources/620.html (accessed on 25 May 2021).

2. Energy Sector Management Assistance Program (ESMAP). The State of Access to Modern Energy Cooking Services. Available online: https:/ / documents1.worldbank.org/curated/en/937141600195758792/pdf/The-State-of-Access-to-Modern-EnergyCooking-Services.pdf (accessed on 25 May 2021).

3. International Energy Agency (IEA). World Energy Outlook 2020. Available online: https://www.iea.org/reports/world-energyoutlook-2020?mode=overview (accessed on 25 May 2021).

4. United Nations High Commissioner for Refugees (UNHCR). Global Trends Forced Displacement in 2019. Available online: https:/ / www.unhcr.org/statistics/unhcrstats/5ee200e37/unhcr-global-trends-2019.html (accessed on 25 May 2021).

5. Environmental Health in Emergencies. Displaced People. Available online: https://www.who.int/environmental_health_ emergencies/displaced_people/en/ (accessed on 25 May 2021).

6. Lahn, G.; Grafham, O. Heat, Light and Power for Refugees. Saving Lives, Reducing Costs. Available online: https://www. chathamhouse.org/sites/default/files/publications/research/2015-11-17-heat-light-power-refugees-lahn-grafham-final.pdf (accessed on 25 May 2021).

7. Albadra, D.; Kuchai, N.; Acevedo-De-los-Rios, A.; Rondinel-Oviedo, D.; Coley, D.; da Silva, C.F.; Rana, C.; Mower, K.; Dengel, A.; Maskell, D.; et al. Measurement and analysis of air quality in temporary shelters on three continents. Build. Environ. 2020, 185, 107259. [CrossRef]

8. Obradovic, M. Protecting Female Refugees against Sexual and Gender-Based Violence in Camps. Available online: https://unu. edu/publications / articles / protecting-female-refugees-against-sexual-and-gender-based-violence-in-camps.html (accessed on 25 May 2021).

9. Tafere, M. Forced displacement and the environment: Its place in national and international climate agenda. J. Environ. Manag. 2018, 224, 191-201. [CrossRef] [PubMed]

10. Fuso-Nerini, F.; Tomei, J.; To, L.S.; Bisaga, I.; Parikh, P.; Black, M.; Borrion, A.; Spataru, C.; Castan Broto, V.; Anandarajah, G.; et al. Mapping synergies and trade-offs between energy and the Sustainable Development Goals. Nat. Energy 2017, 3, 10-15. [CrossRef] 
11. World Health Organization (WHO). Burning Opportunity: Clean Household Energy for Health, Sustainable Development, and Wellbeing of Women and Children. Available online: https://www.google.com/url?sa=t\&rct=j\&q=\&esrc=s\&source= web\&cd=\&ved=2ahUKEwixlrCuoNjxAhWjg_0HHSsGD0UQFjAAegQIBhAD\&url=https\%3A\%2F\%2Fapps.who.int\%2Firis\% 2Fbitstream\%2F10665\%2F206498\%2F1\%2F9789241565264_eng.pdf\&usg=AOvVaw0Tpja15alZI8K94li5raz8 (accessed on 25 May 2021).

12. Whitehouse, K. Adopting a Market-Based Approach to Boost Energy Access in Displaced Contexts. Available online: https: //www.chathamhouse.org/sites/default/files/publications/research/2019-03-25-MEIWhitehouse.pdf (accessed on 25 May 2021).

13. Devictor, X. 2019 Update: How Long Do Refugees Stay in Exile? To Find out, Beware of Averages. Available online: https:/ / blogs.worldbank.org/dev4peace/2019-update-how-long-do-refugees-stay-exile-find-out-beware-averages\#: \{\}: text $=\% 22$ The $\% 20$ average $\% 20$ length\%20of\%20time,are\%20spinning\%20out\%20of\%20control (accessed on 25 May 2021).

14. United Nations High Commissioner for Refugees (UNHCR), United Nations Institute for Training and Research (UNITAR) and Global Plan of Action for Energy Access Solutions in Situations of Displacement (GPA). Clean Energy Challenge. UNHCR-Clean Energy Challenge-Affordable, Reliable and Sustainable Energy for Displaced Persons and Host Communities-September 2020 (PDF). Available online: https://www.unhcr.org/publications/brochures/5f58e6214/clean-energy-challenge-affordable-reliablesustainable-energy-displaced.html (accessed on 25 May 2021).

15. United Nations (UN). Transforming Our World: The 2030 Agenda for Sustainable Development. Available online: https:/ / sustainabledevelopment.un.org/content/documents/21252030\%20Agenda\%20for\%20Sustainable\%20Development\% 20web.pdf (accessed on 25 May 2021).

16. Bellanca, R.; Garside, B. As Approach to Designing Energy Delivery Models That Work for People Living in Poverty. Available online: https:/ / pubs.iied.org/sites/default/files/pdfs/migrate/16551IIED.pdf (accessed on 25 May 2021).

17. Food and Agriculture Organization of the United Nations (FAO) and Practical Action. Key Success Factors and Obstacles for FAO Energy Projects in Humanitarian Settings. Available online: http:/ / www.fao.org/3/ca9913en/ca9913en.pdf (accessed on 25 May 2021).

18. Chatham House. Moving Energy Initiative (MEI). Available online: https:/ / mei.chathamhouse.org/ (accessed on 25 May 2021).

19. SNV. Market Based Energy Access (MBEA) Project-Kakuma Turkana County. Available online: https://snv.org/project/marketbased-energy-access-mbea-project-kakuma-turkana-county (accessed on 25 May 2021).

20. Energypedia. Energy Solutions for Displacement Settings (ESDS) Project. Available online: https://energypedia.info/wiki/ Energy_Solutions_for_Displacement_Settings (accessed on 25 May 2021).

21. United Nations (UN). Agenda for Humanity. Available online: http://agendaforhumanity.org/sites/default/files/Agenda_for_ Humanity_Booklet.pdf (accessed on 25 May 2021).

22. Van Landeghem, L. Private-Sector Engagement. The Key to Efficient, Effective Energy Access for Refugees. Available online: https: / / energy4impact.org/file/1709/download?token=G6vkn3ny (accessed on 25 May 2021).

23. Modern Energy Cooking Services Programme (MECS). Sparking a Revolution. Available online: https://mecs.org.uk/wpcontent/uploads/2020/12/MECS-Brochure-email-version.pdf (accessed on 25 May 2021).

24. World Bank (WB). SE4All Global Tracking Framework. Available online: https://www.worldbank.org/en/topic/energy/ publication/Global-Tracking-Framework-Report (accessed on 25 May 2021).

25. Grafham, O.; Sandwell, P. Harness better data to improve provision of humanitarian energy. Nat. Energy 2019, 4, 993-996. [CrossRef]

26. Gunning, R. The Current State of Sustainable Energy Provision for Displaced Populations: An Analysis; Chatham House: London, UK, 2014.

27. Lehne, J.; Blyth, W.; Lahn, G.; Bazilian, M.; Grafham, O. Energy services for refugees and displaced people. Energy Strategy Rev. 2016, 13, 134-146. [CrossRef]

28. International Finance Corporation (IFC). Private Sector \& Refugees Pathways to Scale. Available online: https://www.ifc.org/ wps/wcm/connect/1c187356-8185-4efe-898c-b78962d30f35/201905-Private-Sector-and-Refugees.pdf?MOD=AJPERES (accessed on 25 May 2021).

29. United Nations High Commissioner for Refugees (UNHCR). Global Strategy for Sustainable Energy. Available online: https: / / www.unhcr.org/5db16a4a4 (accessed on 25 May 2021).

30. Lahn, G. Thinking differently about energy access in displacement situations. In Energy Insight; Oxford Policy Management and UK Aid: Oxford, UK, 2019.

31. Global Alliance of Clean Cookstoves (GACC). Energy Projects in Humanitarian Settings 1983 to 2015-Humanitarian Data Exchange. Available online: https:/ / data.humdata.org/dataset/energy-projects-in-humanitarian-settings (accessed on 25 May 2021).

32. Benka-Coker, M.L.; Tadele, W.; Milano, A.; Getaneh, D.; Stokes, H. A case study of ethanol CleanCook stove intervention and potential scale up in Ethiopia. Energy Sustain. Dev. 2018, 46, 53-64. [CrossRef]

33. Fair Climate Fund. Chad—Solar Cookers for Refugee Families. Available online: https://www.fairclimatefund.nl/en/projects/ chad-solar-cookers-for-refugee-families (accessed on 25 May 2021). 
34. Troconis, I. The Broken Promise of Solar Cooking? The Case of Goudoubo Refugee Camp. Available online: https:/ /blogs.lse.ac.uk/ internationaldevelopment/2018/01/12/the-broken-promise-of-solar-cooking-the-case-of-goudoubo-refugee-camp/ (accessed on 25 May 2021).

35. Solar Cookers International. Nepal. Available online: https://solarcooking.fandom.com/wiki/Nepal (accessed on 25 May 2021$)$.

36. Clark, J. Solar Cooker Offers Ray of Hope for Refugee Environment. Available online: https://www.unhcr.org/news/latest/20 04/6/40c08d4b4/solar-cooker-offers-ray-hope-refugee-environment.html\#: \{\}:text=UNHCR\%20is\%20testing\%20a\%20newly, when \%20they\%20forage\%20for\%20firewood (accessed on 25 May 2021).

37. United Nations Development Program (UNDP). Improving Energy Access in East Sudan's Refugee Crisis. Available online: https://undparabic.exposure.co/improving-energy-access-in-east-sudans-refugee-crisis (accessed on 25 May 2021).

38. Practical Action. Practical Action: Energising the Energy Sector in Sudan. Available online: https://studylib.net/doc/16092096 / practical-action--energising-the-energy-sector-in-sudan (accessed on 25 May 2021).

39. Climate Neutral Group. Solar Cooking Chad. Available online: https:/ /www.climateneutralgroup.com/en/climate-projects / solar-cooking-chad/ (accessed on 25 May 2021).

40. Tran, A.; Bisaga, I.; To, L.S. Landscape Analysis of Modern Energy Cooking in Displacement Settings. Available online: https: // mecs.org.uk/wp-content/uploads/2020/12/Landscape-Analysis-of-MECS-in-Displacement-Settings_17022021.pdf (accessed on 25 May 2021).

41. Global Alliance for Clean Cookstoves (GACC). Cooking Innovations in Humanitarian Settings. Available online: https://www. cleancookingalliance.org/binary-data/RESOURCE/file/000/000/473-1.pdf (accessed on 25 May 2021).

42. Patel, L.; Gross, K. Cooking in Displacement Settings. Engaging the Private Sector in Non-Wood-Based Fuel Supply. Available online: https: / / energy4impact.org/file/2206/download?token=PHsi699L (accessed on 25 May 2021).

43. United Nations High Commissioner for Refugees (UNHCR). Jordan Winterization Report 2017. Available online: https://data2 .unhcr.org/en/documents/download/ 62975 (accessed on 25 May 2021).

44. United Nations High Commissioner for Refugees (UNHCR). Rohingya Refugee Response—Bangladesh. Factsheet—Energy \& Environment. Available online: https:/ / data2.unhcr.org/en/documents/download/83579 (accessed on 25 May 2021).

45. United Nations High Commissioner for Refugees (UNHCR). Niger: Access to Gas Project. Available online: https://www.unhcr. org/afr/niger-access-to-gas-project.html (accessed on 25 May 2021).

46. Rasmussen, E.L.; Thorsen, N.M.; Carstense, L.O.; Grann, J.D. Version 1 ECOCA Pilot Test. Learning Study-Consolidation of Findings across Pilot Contexts. Available online: https:/ / pesitho.com/wp-content/uploads/2020/07/End-Line-Report.pdf (accessed on 25 May 2021).

47. United Nations High Commissioner for Refugees (UNHCR). Alternative Cooking Fuel. Access to Clean Cooking Energy Solutions in Refugee Camps in Rwanda-The Roll Out of Liquified Petroleum Gas (LPG) Cooking Fuel as Alternative to Use of Firewood in Mahama Refugee Camp. Available online: https://globalcompactrefugees.org/article/alternative-cooking-fuel (accessed on 25 May 2021).

48. United Nations High Commissioner for Refugees (UNHCR). Rwanda Country Refugee Response Plan 2020-2021. Available online: https: / / reporting.unhcr.org/sites/default/files/Rwanda\%20Country\%20Refugee\%20Response\%20Plan\%202020-202 1\%20-\%20March\%202020.pdf (accessed on 25 May 2021).

49. Spectrum. Overview of Key Findings from Baseline Survey for the IDP Fuel Transition Project; Spectrum: Yangon, Myanmar.

50. Spectrum. Tender for the Supply of Liquefied Petroleum Gas and Associated Household Cooking Settings in Waing Maw IDP Camps for the Period 9 July 2020-9 December 2020. Available online: https:/ / www.spectrumsdkn.org/en/about/employmentopportunities / 423-tender-for-the-supply-of-liquefied-petroleum-gas-and-associated-household-cooking-settings-in-waingmaw-idp-camps (accessed on 25 May 2021).

51. Action Africa Help International (AAHI). Kenya. Available online: https://www.actionafricahelp.org/kenya/ (accessed on 25 May 2021).

52. Vianello, M. A Review of Cooking Systems for Humanitarian Settings; Chatham House: London, UK, 2016.

53. Bisaga, I.; Huber, S. Tips for Private Sector Engagement for Energy Access in Humanitarian Settings. Available online: https: //www.humanitarianenergy.org/news/latest/humanitarianenergy-private-sector-tips (accessed on 25 May 2021).

54. Willitts-King, B.; Spencer, A. Reducing the Humanitarian Financing Gap. Review of Progress Since the Report of the High-Level Panel on Humanitarian Financing. Available online: https://cdn.odi.org/media/documents/Reducing_the_humanitarian_ financing_gap_WEB.pdf (accessed on 25 May 2021).

55. Shell International, Dalberg Advisors and Vivid Economics. Access to More: Creating Energy Choices for Refugees. Available online: https://www.shell.com/sustainability/_jcr_content/par/text_over_image_caro_395647644/text_over_image_caro_23 7760834/buttonUrl.stream/1595953271615/db4946328e61328b1001fd5534929aa47dfe3db6/shell-enter-energy.pdf (accessed on 25 May 2021).

56. Cohen, Y.; Patel, L. Innovative Financing for Humanitarian Energy Interventions. Available online: https:/ / energy4impact.org/ file/2210/ download?token=mcc7FbdF (accessed on 25 May 2021).

57. Organisation for Economic Co-Operation and Development (OECD). Blended Finance. Available online: https://www.oecd.org/ dac/financing-sustainable-development/blended-finance-principles/ (accessed on 25 May 2021).

58. United Nations High Commissioner for Refugees (UNHCR). Carbon Financing. Available online: https://www.unhcr.org/5500 5b069.pdf (accessed on 25 May 2021). 
59. United Nations (UN). Kyoto Protocol to the United Nations Framework Convention on Climate Change. Available online: https://unfccc.int/resource/docs/convkp/kpeng.pdf (accessed on 25 May 2021).

60. Moner-Girona, M.; Szabo, S.; Rolland, R. Finance Mechanisms and Incentives for Photovoltaic technologies in Developing Countries. Compr. Renew. Energy 2012, 1, 111-141. [CrossRef]

61. Carmichael, D.G.; Lea, K.A.; Balatbat, M.C.A. The financial additionality and viability of CDM projects allowing for uncertainty. Environ. Dev. Sustain. 2016, 18, 129-141. [CrossRef]

62. Gold Standard. Available online: https://www.goldstandard.org/ (accessed on 25 May 2021).

63. Quinn, A.K.; Bruce, N.; Puzzolo, E.; Dickinson, K.; Sturke, R.; Jack, D.W.; Mehta, S.; Shankar, A.; Sherr, K.; Rosenthal, J. An analysis of efforts to scale up clean household energy for cooking around the world. Energy Sustain. Dev. 2018, 46, 1-10. [CrossRef] [PubMed]

64. Mazzucato, M.; Semieniuk, G. Financing renewable energy: Who is financing what and why it matters. Technol. Forecast. Soc. Chang. 2018, 127, 8-22. [CrossRef]

65. World Bank (WB). Funding the Sun. New Paradigms for Financing Off-Grid Solar Companies. Available online: https:/ / documents1.worldbank.org/curated/en/447971581689878643/pdf/Funding-the-Sun-New-Paradigms-for-FinancingOff-Grid-Solar-Companies.pdf (accessed on 25 May 2021).

66. United Nations High Commissioner for Refugees (UNHCR). Kakuma Refugee Camp and Kalobeyei Integrated Settlement. Available online: https:/ / www.unhcr.org/ke/kakuma-refugee-camp (accessed on 25 May 2021).

67. Patel, L. Modern Energy Cooking Concessions for Displaced People; Report; MECS and Energy4Impact: UK, 2021; Forthcoming. Available online: https://mecs.org.uk/energy-4-impact-and-mecs-launch-a-series-of-reports-on-unlocking-clean-cookingfinancing/ (accessed on 25 May 2021).

68. Fay, M.; Martimort, D.; Straub, S. Funding and financing infrastructure: The joint-use of public and private finance. J. Dev. Econ. 2021, 150, 102629. [CrossRef]

69. International Renewable Energy Agency (IRENA). Pay-As-You-Go Models. Innovation Landscape Brief. Available online: https:/ / www.irena.org/-/media/Files/IRENA/Agency/Publication/2020/Jul/IRENA_Pay-as-you-go_models_2020.pdf? la=en\&hash=7A2E7A7FF8B5BAB7748670876667628A39DE40D5 (accessed on 25 May 2021).

70. SNV and Energising Development (EnDev). Promoting Market Based Energy Access for Cooking and Lighting in Kakuma Refugee Camp. Available online: https://snv.org/cms/sites/default/files/explore/download/mbea_external_report_final_for_ uploading.pdf (accessed on 25 May 2021).

71. Perros, T.; Buettner, P.; Parikh, P. MECS Behaviour Change Project Report. Understanding Pay-As-You-Go LPG Customer Behaviour. Available online: https:/ / mecs.org.uk/wp-content/uploads/2021/04/Understanding-Pay-As-You-Go-LPG-CustomerBehaviour.pdf (accessed on 25 May 2021).

72. Bisaga, I. Innovation for off-grid solar rural electrification. In Affordable and Clean Energy. Encyclopedia of the UN Sustainable Development Goals; Filho, W.L., Azul, A., Brandli, L., Salvia, A.L., Wall, T., Eds.; Springer: Cham, Switzerland, 2020.

73. Reichert, P.; Trivella, U. Increasing energy access: The rise of pay-as-you-go solar and innovative financing partnerships. Enterprise Dev. Microfinanc. 2015, 26, 248-261. [CrossRef]

74. Grittner, A.M. Results-Based Financing. Evidence from Performance-Based Financing in the Health Sector; Discussion Paper; Deutsches Institut fur Entwicklungspolitik: Bonn, Germany, 2013.

75. Zhang, Y.; Adams, N. Results-Based Financing to Promote Clean Stoves: Initial Lessons from Pilots in China and Indonesia. LiveWire Knowledge Note Series for the Energy and Extractive Global Practice. 2015. Available online: https:/ / openknowledge. worldbank.org/bitstream/handle/10986/22114/Results0based000China0and0Indonesia.pdf? sequence=5\&isAllowed=y (accessed on 25 May 2021).

76. IMC Worldwide. Results-Based Financing for Clean Cookstoves in Uganda. Available online: https: / documents1.worldbank. org/curated/en/903171468009998836/pdf/884500WP0REPLA0April20140Box385191B.pdf (accessed on 25 May 2021).

77. World Bank (WB). Rwanda Energy Access and Quality Improvement Project. Report No.PAD4005. Available online: https://documents1.worldbank.org/curated/en/819241600653622828/pdf/Rwanda-Energy-Access-and-QualityImprovement-Project.pdf (accessed on 25 May 2021).

78. Energising Development (EnDev). Accelerating Uptake of pico PV Systems and High Tier Cookstoves in Kenya through Results-Based Financing. Available online: https://endev.info/wp-content/uploads/2021/01/pico-PV_systems_and_high_tier_ cookstoves_in_Kenya_through_RBF_report.pdf (accessed on 25 May 2021).

79. United Nations Development Program (UNDP). Social and Development Impact Bonds (Results-Based Financing). Available online: https:/ /www.sdfinance.undp.org/content/sdfinance/en/home/solutions/social-development-impact-bonds.html (accessed on 25 May 2021).

80. Naeem, M.A.; Farid, S.; Ferrer, R.; Shahzad, S.J.H. Comparative efficiency of green and conventional bonds pre- and during COVID-19: An asymmetric multifractal detrended fluctuation analysis. Energy Policy 2021, 153, 112285. [CrossRef]

81. Energy4Impact. Crowd Power. Crowdfunding \& P2P Lending for Energy Access. Available online: https://energy4impact.org/ file/2094/download?token=H2OMM250 (accessed on 25 May 2021).

82. Demir, E.G. Improving Energy Access for Displaced Populations. An Institutional Analysis for the Potential of Community Solar Mini-Grids in Refugee Camps. Available online: https:/ / repository.tudelft.nl/islandora/object/uuid:cdbcf4f8-ece2-44ba-b47e7c9590ce5c61/datastream/OBJ1/ download (accessed on 25 May 2021). 
83. Hujale, M. The Best Way to Achieve Sustainable Energy for Refugees Is to Make Them Partners and Not Just Recipients. Available online: https:/ / www.unhcr.org/innovation/the-best-way-to-achieve-sustainable-energy-for-refugees-is-to-makethem-partners-and-not-just-recipients / (accessed on 25 May 2021).

84. Rosenberg-Jansen, S.; Tunge, T.; Kayumba, T. Inclusive energy solutions in refugee camps. Nat. Energy 2019, 4, 990-992. [CrossRef]

85. Kasirye, B.G.; Clancy, J.; Matinga, M. Fuel Security and Supply Dynamics in Internally Displaced Persons' Camps of Northern Uganda. Available online: https:/ / sites.tufts.edu/jha/archives/462 (accessed on 29 June 2021).

86. Bates, L. Smoke, Health and Household Energy Volume 2. Researching Pathways to Scaling up Sustainable and Effective Kitchen Smoke Alleviation. Available online: https://assets.publishing.service.gov.uk/media/57a08bfd40f0b64974000f02/R8345_Bates_ Vol2_SHHE.pdf (accessed on 25 May 2021).

87. United Nations High Commissioner for Refugees (UNHCR). Operational Update > Rwanda/January 2020. Available online: https: //www.unhcr.org/rw/wp-content/uploads/sites/4/2020/08/UNHCR-RWANDA-Operational-Update-January-2020.pdf (accessed on 25 May 2021).

88. Bellanca, R. Sustainable Energy Provision Among Displaced Populations: Policy and Practice. 2014. Available online: https:// www.chathamhouse.org/sites/default/files/field/field_document/20141201EnergyDisplacedPopulationsPolicyPracticeBellanca. pdf (accessed on 2 July 2021).

89. Patel, L.; Trab Nielsen, S. Energy Solutions for Forcibly Displaced Persons and Their Host Communities: Closing The Financing Gap. 2020. Available online: https:/ / openknowledge.worldbank.org/bitstream/handle/10986/33951/Energy-Solutions-forForcibly-Displaced-Persons-and-Their-Host-Communities-Closing-the-Financing-Gap.pdf?sequence=1\&isAllowed=y (accessed on 2 July 2021).

90. Global Platform for Action for Sustainable Energy Solutions in Situations of Displacement (GPA) Framework for Action. Available online: https:/ / www.humanitarianenergy.org/assets/uploads/gpa_framework_final-compressed.pdf (accessed on 25 May 2021).

91. Bisaga, I.; Hamayun, M. Overcoming the Data Wall: Harnessing Big Data to Understand the Energy Needs of Off-Grid Communities and the Displaced. In Energy Access and Forced Migration; Grafham, O., Ed.; Routledge: London, UK, 2019; ISBN 9781138543386.

92. Pascucci, E. More logistics, less aid: Humanitarian-business partnerships and sustainability in the refugee camp. World Dev. 2021, 142, 105424. [CrossRef]

93. Price, M. Modern Energy Cooking Services: An Urban Perspective. Working Paper Apr/2021. Available online: https://mecs. org.uk/wp-content/uploads/2021/04/modern-energy-cooking-services-an-urban-perspective-1.pdf (accessed on 25 May 2021). 